


\section{Comparative Analysis of Means for Financial Support of the Common Agricultural Policy in 2007-2013 as in Relation to 2014-2020}

Keywords: financial instruments, national envelope, Pillars of the CAP, national ceilings Słowa kluczowe: instrumenty finansowe, koperta krajowa, filary WPR, pułapy krajowe

\section{Introduction}

The Common Agricultural Policy (CAP) is one of the policies, which in the recent years has been subjected to permanent reforms. These changes resulted from the need of carrying out the adjustment processes and meeting the relevant expectations from the point of view of the society.

The main trends concerned mostly the environment, quality and safety of food and territorial balance. The accepted framework of financing of the CAP enabled to face the challenges linked with the competitiveness and sustainability of agriculture and the rural areas across the EU. Over the years of introducing the CAP, the European agricultural model has been developed, thanks to which food security is not only ensured for the EU citizens, but to some extent it is involved in the delivery of food for the whole world. The EU is working particularly well with the developing countries, helping them in the long-term development of their agricultural sectors. ${ }^{1}$ In the report of Lyon, it is stated that the CAP objectives, as set out in Art. 39 of the Treaty on the Functioning of the European Union (TFEU), are to

* Dr hab. Bartosz Mickiewicz, prof. nadzw. ZUT; Robert Jurczak, Zakład Ekonomii Środowiska, Katedra Nieruchomości, Agrobiznesu i Ekonomii Środowiska, Zachodniopomorski Uniwersytet Technologiczny, bartosz.mickiewicz@zut.edu.pl

A. Oskam, G. Meester, H. Silvis, EU Policy for Agriculture, Food and Rural Areas, Wageningen 2010. 
increase the agricultural productivity, to ensure a fair standard of living for the agricultural community, to stabilize markets, and to assure the availability of supplies and reasonable prices for supplies to consumers. ${ }^{2}$ Until now, the Common Agricultural Policy has achieved its objectives to a large extent and contributed to the promotion of the EU integration, territorial cohesion in Europe, and the functioning of the common market. Still, the agricultural policy only partially contributed to a fair standard of living for the agricultural community and has not yet reached the stabilization of markets, as markets have become extremely volatile which threatens food security. Agriculture and forestry remain significant sectors of the economy while providing essential public goods by maintaining natural resources and the landscapes of cultural values, which are a prerequisite for all human activities in rural areas. The agricultural sector even now contributes predominantly to achieving the aims concerning the climate and energy in the EU, in particular those relating to renewable energy from agricultural biomass. Bioenergy sources shall also help to reduce the energy dependency of the EU, and, in the context of the rise of energy prices, to create new jobs and increase the incomes in the agro-food sector. ${ }^{3}$

\section{Material, purpose and scope of research}

A characteristic feature of the financing of the CAP is that the share of agricultural expenditure in the budget of the European Union has been systematically reduced for several years. In the early eighties of the twentieth century, the CAP expenses accounted for $66 \%$ of the EU budget, but in a further budget they fell to $40 \%$, and in the period of 2014-2020 they are foreseen for just 37\%.

This decrease is a derivative of the general decrease in the budget under the multiannual financial framework to the level of EUR 908.4 billion, while in the previous term this sum exceeded EUR 1 trillion. In this situation, the division of the financial instruments between the two Pillars and between the countries has become an important indicator of the implementation of the equal access to public assistance. The main objective of the study was a comparative analysis of the CAP implementation in the European Union in the two frames of reference, namely, between the Pillars of the CAP and between the two groups of the Member States. Therefore, the targeted countries were divided into two groups, including the older Member States, which shall bear a code of EU-15, and the new Member States, bearing the code of NUE-13. It is important to be aware that the last country (Croatia), which joined the EU in 2013, participates in the public ex-

\footnotetext{
G. Lyon, Draft report on the future of the Common Agricultural Policy after 2013, DG ARDI, Brussels 2010.

3 Rural Development In The European Union, DG AGRI Report, Statistical and Economic Information Report 2011, December 2011.
} 
penditure only from the programming period of 2014-2020. Such a division is supported by the regulations of the EU supportive divisions defining the national ceilings, which are detailed in the two separate systems. The above jurisdiction concerns particularly the programming period of 2007-2013. Based on the value of the paper and the result of the research, it can be argued that there are significant historical reasons that do not allow the standardization of payments, despite the efforts of the new Member States to adopt a single reference plane. The study was based mainly on the official documents of the EP and the Council Regulations (EU), which form the basis for the development of the national programmes.

\section{Characteristics of the general objectives and tasks of the Common Agricultural Policy}

The Common Agricultural Policy in the context of the 1992 MacSharry reform moved the focus from the support of the market to the support of the agricultural producers. Maintaining the existing prices on agricultural products was replaced by the direct payments. It has been adopted that from that time it should be reasonable to provide the CAP within the two Pillars with the first Pillar linked to direct payments, and the second Pillar with rural development. Through successive reforms, ${ }^{4}$ the agriculture has become more market-oriented while retaining the support for agricultural producers, and at the same time it improved the consistency of the requirements for the environmental protection. ${ }^{5}$ Within the CAP for 2007-2013, it was adopted to carry out the tasks which sought to raise agricultural productivity by promoting technical progress, the rationality of production, and the optimization of production factors. In the longer CAP reform (2014-2020), there are three key objectives for implementation: viable food production, sustainable management of natural resources and the activities in the sphere of the climate, balanced territorial development. The adopted CAP reform will support the growth of competitiveness and the real performance in food and environment security. Thus, the reformed CAP comprises Pillar I, which is 'greener' and based on the fair distribution, whereas Pillar II is concentrated on competitiveness and innovation, climate and environment change. In the strategy for a smart and sustainable growth 'Europe 2020', supported by the social circles, it was stated that the CAP will continue to be based on the two Pillars within which complementary measures will be used to achieve the same objectives. Pillar I of the CAP will cover direct payments and market measures to ensure a basic annual income support to the EU farmers and a support in case of specific market disturbances.

\footnotetext{
4 Agenda 2000. The Health Check 2008.

M. Shucksmith, K.J. Thomson, D. Roberts, The CAP and the Regions: The Territorial Impact of the Common Agricultural Policy, CABI Publishing, London 2005.
} 
Within the Pillar II of the CAP, the Member States shall prepare and will co-finance rural development programmes. Maintaining the two-Pillar structure of the CAP does not meet any denial from the Member States.

\section{Criteria and procedures for financing of the Common Agricultural Policy}

In 2000-2006 the CAP was financed from one fund, i.e. from the European Agricultural Guidance and Guarantee Fund with the Guarantee Section being responsible for direct payments, whilst the Guidance Section was responsible for rural development. In the next seven years of the programming and financing of the EU policies covering the years of 2007-2014, the agricultural sector and the rural areas were financed from the two separate funds. The first one, the European Agricultural Guarantee Fund, financed the activities related to direct payments, market intervention and veterinary instruments. The second fund, the European Agricultural Fund for Rural Development, financed the activities related to the development of the rural areas. The new financial rules were to harmonize and simplify the implementation and monitoring of aid activities and spending. The support for agricultural production in the EU was increasingly being carried out through direct payments to the farmers, and less and less by maintaining a high level of prices. The adopted legal framework of the future CAP foresees continuation for the maintenance of these two separate funds. ${ }^{6}$ Under the Lisbon Treaty for the period of 2014-2020, the role of the European Parliament, which in 2013 adopted the Regulation on the new multiannual financial framework and the Interinstitutional Agreement on the sound financial management, has increased. Under the new multi-annual financial framework, an overall budget for the Department of Management of Natural Resources and Their Protection, integrally connected with the Common Agricultural Policy, was set up.

\section{Formation of support schemes for direct payments (2007-2013 and 2014-2020)}

The area payments are one of the main instruments for implementing the Common Agricultural Policy, which is responsible for the support and stabilization of agricultural incomes, reducing the production costs and maintaining the production in the disadvantaged areas. Direct payments, which are intended to support agriculture, to ensure food security, and to take care of the sustainable rural development may be counted as subsequent subsidies. On the one

6 Implementation and Vision of CAP. CAP in the 27 EU Member States, Directorate-General for Agriculture and Rural Development, Brussels 2008.

7 Council Regulation (EC) No. 1782/2003 of 29 September 2003 establishing common rules for direct support schemes under the common agricultural policy, and establishing certain support schemes for farmers. 
hand, out of the two existing payment systems, the Single Payment Scheme (SPS), built on historical standards, which dominate in the older Member States, is more important. On the other hand, the Single Area Payment Scheme (SAPS) was supposed to be a transitional and simplified income support system, from which the new Member States could benefit on a voluntary basis at the time of the accession to the European Union. ${ }^{8}$ The successive reforms of the CAP caused that direct payments have become an important instrument of this policy, responsible for supporting and stabilizing agricultural incomes. The separation of payments from current production in order to promote a more market-oriented and sustainable agriculture, and hence to support agricultural incomes, became an important decision. ${ }^{9}$ The task was to keep the area payment in a good agricultural and environmental condition, to compensate for the costs associated with the fulfillment of the Community requirements and with the principles of cross-compliance, ensuring equal conditions of competition in the unitary agricultural and food market. Another objective was to protect natural resources, to prevent climate change, to improve water management, conservation of biodiversity, and to promote the renewable energy. ${ }^{10}$ The principles of direct payments, implemented in 2013, have been extended until 2014, due to the unfinished negotiations in the European Parliament and the Council (EU). Therefore, in 2014 the same types of payments were granted that had been applied with reference to 2013, with the exception of the complementary basic payment (the so-called sector I), and a supplementary payment to the cultivation surface intended for animal feed, grown on a permanent grassland (livestock payments). The European Parliament and Council Regulation (EU) No. 1307/2013 established the legislation related to the area payment scheme from 2015. The EU legislation introduces two types of payments, that is the obligatory ones which shall be implemented, and the voluntary, which depend on the decision of a certain country. The single area payments, payments on planting and payments for young farmers belong to the mandatory activities. In turn, the voluntary payments include payments for small farms, payments connected with production, the transitional national support, and additional payments. ${ }^{.1}$ Table 1 reflects the formation of the area payments. The direct support schemes are varied in the EU for historical reasons. The Single Payment Scheme (SPS) is used in the EU-15 countries. In the SPS system, there are three types of payments: historical, regional, and mixed (hybrid). Under the historical type, such rights are determined on the basis of the payments received by a farmer in the reference period of 2000-2002, which means that the amount of direct payments corresponded

\footnotetext{
8 Implementation and Vision of CAP....

9 Council Regulation (EC) No. 73/2009 of 19 January 2009 establishing common rules for direct support schemes for farmers under the common agricultural policy, and establishing certain support schemes for farmers.

10 The effect of direct payments and other instruments of the Common Agricultural Policy on the Polish agri-food markets, ed. S. Gburczyk, IAFE, Warsaw 2006

11 EP and Council Regulation (EU) No. 1307/2013 of 17 December 2013 establishing rules for direct payments to farmers under support schemes under the common agricultural policy.
} 
to the average total amount of payments during that period and was paid per hectare. Under the regional system, these arrangements were made on the basis of the payments received by all farmers in the reference period of 2000-2002. Subsequently, the established regional financial envelope was divided in accordance with the total payment surface in the region. The Member States could also decide to use the hybrid (mixed) model, which is a combination of these two payment models. As a result, the amounts of direct payments in the older Member States reached a relatively high level. ${ }^{12}$

Table 1. Basic figures on agriculture in the $28 \mathrm{EU}$ states (2012)

\begin{tabular}{|c|c|c|c|c|c|c|c|c|c|}
\hline $15 \mathrm{EU}$ states & 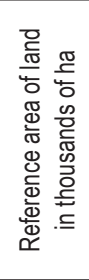 & 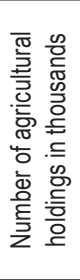 & 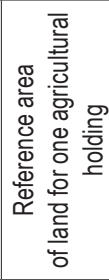 & 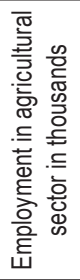 & $\begin{array}{c}13 \text { new EU } \\
\text { states }\end{array}$ & 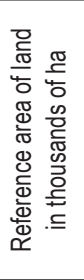 & 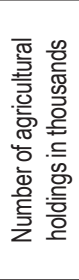 & 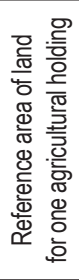 & 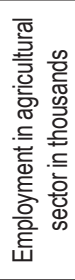 \\
\hline Austria & 2878 & 149 & 19.3 & 202 & Bulgaria & 4476 & 357 & 12.5 & 677 \\
\hline Belgium & 1358 & 42 & 32.3 & 64 & Cyprus & 118 & 36 & 3.1 & 18 \\
\hline Denmark & 2647 & 41 & 64.6 & 73 & $\begin{array}{l}\text { Czech } \\
\text { Republic }\end{array}$ & 3484 & 23 & 151.5 & 152 \\
\hline Finland & 2291 & 63 & 36.4 & 114 & Estonia & 941 & 19 & 49.5 & 26 \\
\hline France & 27837 & 507 & 54.9 & 753 & Hungary & 4686 & 534 & 8.8 & 291 \\
\hline Germany & 16704 & 298 & 56.1 & 658 & Latvia & 1796 & 83 & 21.6 & 75 \\
\hline Greece & 3478 & 717 & 4.9 & 513 & Lithuania & 2743 & 200 & 13.7 & 116 \\
\hline Ireland & 4991 & 140 & 35.7 & 83 & Malta & 11 & 12 & 0.9 & 5 \\
\hline Italy & 12856 & 1616 & 8.0 & 965 & Poland & 14447 & 1499 & 9.6 & 2036 \\
\hline Luxembourg & 131 & 2 & 65.5 & & Romania & 13306 & 3724 & 3.6 & 2962 \\
\hline Netherlands & 1872 & 71 & 26.4 & 226 & Slovakia & 1896 & 24 & 79 & 71 \\
\hline Portugal & 3668 & 304 & 12.1 & 520 & Slovenia & 483 & 74 & 6.5 & 79 \\
\hline Spain & 23753 & 967 & 24.6 & 755 & NUE-12 & 48387 & 6585 & - & 6508 \\
\hline Sweden & 3066 & 70 & 43.5 & 92 & Croatia & 1326 & 177 & 7.5 & 186 \\
\hline Great Britain & 15686 & 183 & 85.7 & 408 & NUE-13 & 49713 & 6762 & - & 6694 \\
\hline UE-15 & 123216 & 5170 & - & 5426 & & & & & \\
\hline UE-28 & 172929 & 11932 & - & 12120 & & & & & \\
\hline
\end{tabular}

Source: Report of the Commission (EU) for 2012, Agriculture in the European Union, Statistical and Economic Information, February 2013.

While analyzing the UAA surfaces, it should be pointed out that of the total area of 172.9 million ha in the European Union, 49.7 million ha or $28.7 \%$ account for the new Member States. At the same time, the new Member States have a poorer agrarian structure (with the exception of the Czech Republic), and are characterized by the hypertrophy of the people em-

12 Rural Development In The European Union, DG AGRI Report, Statistical and Economic Information Report 2011, December 2011. 
ployed in agriculture (55.2\% of the total), which results in the lower productivity. Referring these results to the level of the financial support intended for the first Pillar of the CAP, one can state that in 2007-2013 EUR 246.2 billion (86.0\%) accounted for the EU-15, while for the NUE-12 countries only EUR 39.98 billion (14.0\%) with the overall budget amounting to EUR 286.22 billion. This placed the new Member States at a disadvantage, resulting in a limited ability to compete in the European common agricultural market. The situation will probably change in a long-term financing for 2014-2020, where financial instruments provided to the Pillar I of the CAP are set at a level of EUR 290.30 billion, with EUR 229.23 billion (77.7\%) planned for the first group of the countries, and EUR 65.74 billion (22.3\%) for the second one. ${ }^{13}$

Table 2. National ceilings for direct support included in a financial envelope for the $15 \mathrm{EU}$ states (in millions of EUR)

\begin{tabular}{|c|c|c|c|c|c|c|}
\hline \multirow[b]{2}{*}{ State } & \multicolumn{3}{|c|}{$2007-2013$} & \multicolumn{3}{|c|}{$2014-2020$} \\
\hline & $\begin{array}{c}\text { the overall budget } \\
\text { of the CAP }\end{array}$ & $\begin{array}{l}\text { the first Pillar } \\
\text { of the CAP }\end{array}$ & percent & $\begin{array}{c}\text { the overall budget } \\
\text { of the CAP }\end{array}$ & $\begin{array}{l}\text { the first Pillar } \\
\text { of the CAP }\end{array}$ & percent \\
\hline Austria & 9,117 & 5,205 & 57.1 & 8,783 & 4,846 & 55.2 \\
\hline Belgium & 4,680 & 4,262 & 91.1 & 4,202 & 3,651 & 86.9 \\
\hline Denmark & 7,646 & 7,201 & 94.2 & 6,926 & 6,297 & 90.9 \\
\hline Finland & 6,038 & 3,958 & 65.5 & 6,047 & 3,667 & 60.7 \\
\hline France & 64,865 & 58,423 & 90.0 & 62,397 & 52,487 & 84.1 \\
\hline Germany & 48,420 & 40,307 & 83.2 & 43,812 & 35,594 & 81.3 \\
\hline Greece & 18,188 & 14,480 & 79.6 & 18,152 & 13,956 & 76.9 \\
\hline Ireland & 11,723 & 9,383 & 80.0 & 10,680 & 8,491 & 79.5 \\
\hline Italy & 35,265 & 26,973 & 76.5 & 37,096 & 26,666 & 71.9 \\
\hline Luxembourg & 349 & 259 & 74.2 & 347 & 247 & 71.2 \\
\hline Netherlands & 6,432 & 5,946 & 92.4 & 5,914 & 5,307 & 79.7 \\
\hline Portugal & 7,936 & 4,007 & 50.5 & 8,127 & 4,069 & 50.1 \\
\hline Spain & 39,894 & 32,680 & 81.9 & 42,352 & 34,061 & 80.4 \\
\hline Sweden & 7,156 & 5,331 & 74.5 & 6,632 & 4,887 & 73.7 \\
\hline Great Britain & 29,737 & 27,827 & 93.6 & 27,583 & 25,003 & 90.7 \\
\hline EU-15 & 297,446 & 246,242 & 82.8 & 289,050 & 229,229 & 79.3 \\
\hline
\end{tabular}

Source: European Parliament and Council Regulations (EU) for the said periods of programming.

The analysis of the financial support under the direct support system among the EU-15 countries shows that in the first programming period of 2007-2013 82.8\% of the means of the overall budget were allocated to the CAP Pillar I, with the lowest usage rates of aid recorded in Austria (57.1\%), Portugal (50.5\%), and Finland (66.5\%). In the next term of the CAP programme for 2014-2020, less financial instruments (by 6.9\%) are allocated for the first CAP Pillar. It means that in all of the older Member States, the support related to the implementation of payments under the CAP Pillar I has been decreased.

13 EP and Council Regulation (EU) No. 1307/2013 of 17 December 2013 establishing rules for direct payments to farmers under support schemes under the common agricultural policy. 
Table 3. National ceilings for direct support included in a financial envelope for the new 13 UE states (in millions of EUR)

\begin{tabular}{|l|r|r|r|r|r|r|}
\hline \multirow{2}{*}{ State } & \multicolumn{3}{|c|}{$2007-2013$} & \multicolumn{2}{c|}{$2014-2020$} \\
\cline { 2 - 7 } & $\begin{array}{c}\text { the overall budget } \\
\text { of the CAP }\end{array}$ & $\begin{array}{c}\text { the first pillar } \\
\text { of the CAP }\end{array}$ & percent & $\begin{array}{c}\text { the overall budget } \\
\text { of the CAP }\end{array}$ & $\begin{array}{c}\text { the first pillar } \\
\text { of the CAP }\end{array}$ & percent \\
\hline Bulgaria & 5,098 & 2,489 & 48.9 & 7,675 & 5,336 & 69.5 \\
\hline Cyprus & 379 & 217 & 57.0 & 480 & 348 & 72.5 \\
\hline Czech Republic & 7,316 & 4,500 & 61.5 & 8,285 & 6,115 & 73.8 \\
\hline Estonia & 1,209 & 494 & 40.9 & 1,733 & 1,007 & 58.1 \\
\hline Hungary & 10,298 & 6,493 & 63.1 & 12,346 & 8,891 & 72.0 \\
\hline Latvia & 1,767 & 725 & 41.1 & 2,686 & 1,717 & 64.2 \\
\hline Lithuania & 3,611 & 1,868 & 51.7 & 4,861 & 3,248 & 66.8 \\
\hline Malta & 97 & 20 & 20.6 & 133 & 34 & 25.6 \\
\hline Poland & 28,269 & 15,039 & 53.2 & 32,088 & 21,147 & 65.9 \\
\hline Romania & 13,524 & 5,502 & 40.7 & 20,955 & 12,939 & 61.7 \\
\hline Slovakia & 3,892 & 1,923 & 49.4 & 4,599 & 2,709 & 58.9 \\
\hline Slovenia & 1,612 & 712 & 44.2 & 1,792 & 954 & 53.2 \\
\hline NUE-12 & 77,072 & 39,982 & 51.9 & 97,633 & 64,445 & 66.0 \\
\hline Croatia & 0,0 & 0,0 & 0.0 & 3,621 & 1,296 & 35.8 \\
\hline NUE-13 & & & & 101,254 & 65,741 & 64.9 \\
\hline
\end{tabular}

Source: European Parliament and Council Regulations (EU) for the said periods of programming.

The situation is changing slightly in the context of the area of payment systems in the new Member States. During the planning of the budgetary framework for 2007-2013, 51.9\% of the total budget is foreseen for direct payments. The lowest levels of the support related to the general budget of the CAP were noted in Malta (20.6\%), Romania (40.7\%), Estonia (40.9\%), and Latvia (41.1\%). In the next financial perspective for 2014-2020, the expenditures to the CAP Pillar I are increased to $64.9 \%$ of the total budget, which is a positive phenomenon observed in all NUE-13 countries. ${ }^{14}$

\section{Financing of rural development programmes for 2007-2013 compared to 2014-2020}

The rural development programmes are an instrument of policy, referred to the second CAP Pillar. Objectives, priorities, and principles concerning the use of the actions anticipated by the EU budget, are defined in the legislation on RDP. The RDP budget will support the activities not only for agricultural holdings, but also for the socio-economic development of rural areas. The basic principles of the rural development policy for the period of 2007-2013 were included in the EU legislation on the support for the rural development (EAFRD).

14 EP and Council Regulation (EU) no. 1307/2013 of 17 December 2013 establishing rules for direct payments to farmers under support schemes under the common agricultural policy. 
The regulation indicates that the strategic objectives should identify the areas important for the realization of the priorities of the Community, in particular in relation to a sustainable development, and ensure the consistency with other EU policies. ${ }^{15}$ It was assumed that the rural development policy is focused on three key areas: the agro-food economy, the environment, and the wider economy and rural population. ${ }^{16}$ In yet another term of the support regulating the shape of the Rural Development Programme for 2014-2020, the EP and the Council Regulation (EU) No. 1305/2013 was the primary legal document. This regulation outlines a new strategy for the rural development, which indicates a need to focus on a limited number of the core priorities relating to their development. The priorities will be related to the transfer of knowledge and innovation, the profitability and competitiveness of farms, and the promotion of innovative technologies. The applied instruments of this policy relate to investment, infrastructure, ecosystems, as well as to the support for the less favored areas, environmental protection measures, and the measures on climate change. More attention should be directed to the innovative ideas in business and government activities at the local level. A novelty in this issue lied in the fact that the regulation on the rural development was based on a strategic approach, which meant that the Member States would develop the strategies and programmes on the SWOT analysis. The new delivery mechanism aims to improve the efficiency of the strategic approach by establishing the common objectives and the necessary adjustments. ${ }^{17}$

With regard to the support for the rural development, stronger links with other policies are proposed, in particular with the cohesion policy, through the inclusion of the second CAP Pillar in the Common Strategic Framework. When defining the common rules for all the funds in the CSF, the second CAP Pillar should allow activities in a coordinated and complementary way to the first CAP Pillar, so the strengthening should occur through the synergy effect. Financial instruments related to the rural development are fundamentally different from those aimed at direct subsidies. The area payments are forwarded to all the farmers who possess agricultural holdings exceeding 1 ha, and at the same time meet the criteria of cross-compliance and other obligations under the European legislation. In contrast, public spending to the rural development is next forwarded to farmers, and also to a certain group of producers (for example, to a group of farmers) or to a bigger social community (e.g. Leader). In terms of direct payments, a farmer gets these payments annually, while he may receive the assistance under the RDP only once. Besides, this help is sometimes divided into installments. Not all the measures in the RDP are fully

15 Council Regulation (EC) no. 1698/2005 of 20 September 2005. On support for rural development by the European Agricultural Fund for Rural Development.

16 Ibidem.

17 European Parliament and Council Regulation (EU) no. 1305/2013 of 17 December 2013. On support for rural development by the EAFRD and repealing Council Regulation (EC) no 1698/2005. 
covered under the public expenditures, because the beneficiary contribution is required in some of them.

The total budget of the CAP on the financial perspective of 2007-2013 covering the first and second CAP Pillars amounted to EUR 374.51 billion, where on the first CAP Pillar it was allocated EUR 286.22 billion (76.4\%), while on the second one EUR 88.29 billion (23.6\%). In the next multiannual framework programme for 2014-2020, the general budget of the CAP has increased to EUR 390.30 billion (about $4.2 \%$ increase). EUR 294.97 billion (75.6\%) of it are foreseen on the first CAP Pillar, while EUR 95.33 billion $(24.4 \%)$ on the second one. In view of these data, it can be concluded that the budget has remained at the same level, taking into account the adoption of a new Member State. In contrast, the general comparative analysis of the CAP budget indicates that the funds for the development of rural areas will increase from EUR 88.3 billion to EUR 95.3 billion (7.9\%). Furthermore, the research on the second CAP Pillar shows the phenomenon of the growth of the means targeting the EU-15 states and the diminishing of the means at the disposal of the NUE-13 states. On the other hand, a closer examination of this phenomenon within the EU-15 states shows that these countries stand on a high level of technical equipment and infrastructure in the rural areas, so in this respect they use the EAFRD means on a small range. Denmark $(5.8 \%$ and $9.1 \%$ respectively), Great Britain (6.4\% and 9.3\%), the Netherlands (7.6\% and 20.3\%), and Belgium $(8.9 \%$ and $13.1 \%)$ may be counted towards such countries.

Table 4. National ceilings for support of rural development in the $15 \mathrm{EU}$ states (in millions of EUR)

\begin{tabular}{|c|c|c|c|c|c|c|}
\hline \multirow[b]{2}{*}{ State } & \multicolumn{3}{|c|}{$2007-2013$} & \multicolumn{3}{|c|}{$2014-2020$} \\
\hline & $\begin{array}{c}\text { the overall budget } \\
\text { of the CAP }\end{array}$ & $\begin{array}{c}\text { the second pillar } \\
\text { of the CAP }\end{array}$ & percent & $\begin{array}{c}\text { the overall budget } \\
\text { of the CAP }\end{array}$ & $\begin{array}{c}\text { the second pillar } \\
\text { of the CAP }\end{array}$ & percent \\
\hline Austria & 9,117 & 3,911 & 42.9 & 8,783 & 3,937 & 44.8 \\
\hline Belgium & 4,680 & 419 & 8.9 & 4,202 & 551 & 13.1 \\
\hline Denmark & 7,646 & 445 & 5.8 & 6,926 & 629 & 9.1 \\
\hline Finland & 6,038 & 2,080 & 34.5 & 6,047 & 2,380 & 39.3 \\
\hline France & 64,865 & 6,442 & 10.0 & 62,397 & 9,910 & 15.9 \\
\hline Germany & 48,420 & 8,113 & 16.8 & 43,812 & 8,218 & 18.7 \\
\hline Greece & 18,188 & 3,707 & 20.4 & 18,152 & 4,196 & 23.1 \\
\hline Ireland & 11,723 & 2,340 & 20.0 & 10,680 & 2,189 & 20.5 \\
\hline Italy & 35,265 & 8,292 & 23.5 & 37,096 & 10,430 & 28.1 \\
\hline Luxembourg & 349 & 90 & 25.8 & 347 & 100 & 28.8 \\
\hline Netherlands & 6,432 & 487 & 7.6 & 5,914 & 607 & 20.3 \\
\hline Portugal & 7,936 & 3,929 & 49.5 & 8,127 & 4,058 & 49.9 \\
\hline Spain & 39,894 & 7,214 & 18.1 & 42,352 & 8,291 & 19.6 \\
\hline Sweden & 7,156 & 1,826 & 25.5 & 6,632 & 1,745 & 26.3 \\
\hline Great Britain & 29,737 & 1,910 & 6.4 & 27,583 & 2,580 & 9.3 \\
\hline EU-15 & 297,446 & 51,205 & 17.2 & 289,050 & 59,821 & 20.7 \\
\hline
\end{tabular}

Source: European Parliament and Council Regulations (EU) for the said periods of programming. 
The situation was different in the new Member States, which stand at a lower level of economic development. They have to resolve the problem of whether to allocate more funds for area payments, which are experienced in every agricultural holding, or transfer them to a wider rural community. Generally, in all the NUE-13 countries, the national ceilings on the rural development have been decreased, with the greatest reductions in Bulgaria (from 51.1\% to 30.6\%), Romania (from 59.3\% to 38.3\%) and Latvia (from $58.9 \%$ to $35.8 \%$ ). In these countries, the lowest ceilings of direct payments are reported, not ignoring the fact that Bulgaria and Romania joined the EU only in 2007.

Table 5. National ceilings for support of rural development in the new 13 UE states (in millions of EUR)

\begin{tabular}{|c|c|c|c|c|c|c|}
\hline \multirow[b]{2}{*}{ State } & \multicolumn{3}{|c|}{$2007-2013$} & \multicolumn{3}{|c|}{$2014-2020$} \\
\hline & $\begin{array}{c}\text { theoverallbudget } \\
\text { of the CAP }\end{array}$ & $\begin{array}{c}\text { the second } \\
\text { pillar of the CAP }\end{array}$ & percent & $\begin{array}{c}\text { theoverallbudget } \\
\text { of the CAP }\end{array}$ & $\begin{array}{c}\text { the second } \\
\text { pillar of the CAP }\end{array}$ & percent \\
\hline Bulgaria & 5,098 & 2,609 & 51.1 & 7,675 & 2,339 & 30.5 \\
\hline Cyprus & 379 & 163 & 43.0 & 480 & 132 & 27.5 \\
\hline Czech Republic & 7,316 & 2,816 & 38.5 & 8,285 & 2,170 & 26.2 \\
\hline Estonia & 1,209 & 715 & 59.1 & 1,733 & 726 & 41.9 \\
\hline Hungary & 10,298 & 3,806 & 36.9 & 12,346 & 3,455 & 28.0 \\
\hline Latvia & 1,767 & 1,041 & 58.9 & 2,686 & 969 & 35.8 \\
\hline Lithuania & 3,611 & 1,743 & 48.3 & 4,861 & 1,613 & 33.2 \\
\hline Malta & 97 & 77 & 79.4 & 133 & 99 & 74.4 \\
\hline Poland & 28,269 & 13,230 & 46.8 & 32,088 & 10,941 & 34.1 \\
\hline Romania & 13,524 & 8,023 & 59.3 & 20,955 & 8,016 & 38.3 \\
\hline Slovakia & 3,892 & 1,969 & 50.6 & 4,599 & 1,890 & 44.1 \\
\hline Slovenia & 1,612 & 900 & 55.8 & 1,792 & 838 & 46.8 \\
\hline NUE-12 & 77,072 & 37,092 & 48.1 & 97,633 & 33,188 & 34.0 \\
\hline Croatia & 0,0 & 0,0 & 0.0 & 3,621 & 2,325 & 64.2 \\
\hline NUE-13 & 0,0 & 0,0 & 0.0 & 101,254 & 35,513 & 35.1 \\
\hline
\end{tabular}

Source: European Parliament and Council Regulations (EU) for the said periods of programming.

\section{Concluding Remarks}

The comparative analysis concerning the two groups of the Member States and the two CAP Pillars on the background of the programming periods of 2007-2013 and 2014-2020 indicates new phenomena in the Common Agricultural Policy.

The research has shown that the cumulative budgets of the Common Agricultural Policy in the studied period remained almost at the same level, taking into account the increase in the number of the EU members to 28 in 2007. There have been no significant shifts between the Pillars of the financial instruments, while slightly more resources were forwarded to the direct payments in the new Member States. These changes respond to a broad discussion that was waged before the introduction of the multiannual financial 
framework for 2014-2020. The Common Agricultural Policy will undergo a gradual modification, involving more support to the natural environment in connection with the climate, and to a lesser scope will promote the growth of commodity production.

A characteristic feature of this evolution is a wide range and the pace of changes of the CAP, much greater than they were in the previous periods. In the period preceding the CAP programming, not only the rules, which constitute the first Pillar of the CAP related to direct payments and market intervention, but also the regulations establishing the second CAP Pillar, linked to the development of the rural areas, were assessed.

The delayed accession (2014) to the programming of the direct payments system and the rural development, followed by consulting these programmes by the EU, may interfere with the implementation of these measures in particular years.

Literature

Agenda 2000.

Council Regulation (EC) no. 1782/2003 of 29 September 2003 establishing common rules for direct support schemes under the common agricultural policy, and establishing certain support schemes for farmers.

Council Regulation (EC) no. 1698/2005 of 20 September 2005. On support for rural development by the European Agricultural Fund for Rural Development.

Council Regulation (EC) no. 73/2009 of 19 January 2009 establishing common rules for direct support schemes for farmers under the common agricultural policy, and establishing certain support schemes for farmers.

Rural Development In The European Union, DG AGRI Report, Statistical and Economic Information Report 2011, December 2011.

EP and Council Regulation (EU) no. 1307/2013 of 17 December 2013 establishing rules for direct payments to farmers under support schemes under the common agricultural policy.

European Parliament and Council Regulation (EU) no. 1305/2013 of 17 December 2013. On support for rural development by the EAFRD and repealing Council Regulation (EC) no. 1698/2005.

The effect of direct payments and other instruments of the Common Agricultural Policy on the Polish agri-food markets, ed. S. Gburczyk, IAFE, Warsaw 2006.

Implementation and Vision of CAP, 2008, CAP in the 27 EU Member States, Directorate-General for Agriculture and Rural Development, Brussels 2008.

Lyon G., Draft report on the future of the Common Agricultural Policy after 2013, DG ARDI, Brussels 2010.

Oskam A., Meester G., Silvis H., EU Policy for Agriculture, Food and Rural Areas, Wageningen 2010.

Report of the Commission (EU) for 2012, Agriculture in the European Union, Statistical and Economic Information, February 2013.

Shucksmith M., Thomson K.J., Roberts D., The CAP and the Regions: The Territorial Impact of the Common Agricultural Policy. CABI Publishing, London 2005.

The Health Check 2008. 


\begin{abstract}
The study takes up the funding of the Common Agricultural Policy, in which the two groups of the Member States, the two CAP Pillars and the two programming periods of 2007-2013 and of 2014-2020, were under analysis. The research shows that the older Member States (EU-15), possessing $71.3 \%$ of the reference area of the land used for agriculture, participated in the formation of the means for financial support under the first the CAP Pillar at the level of $84.0 \%$ in the first period, and at the level of $77.7 \%$ in the second one. This means that within the European Union there is a gradual tendency for the compensation of direct payments. As for the second CAP Pillar, which is the mirror reflection of the overall situation of the total budget of the Common Agricultural Policy, it covers one third of the financial support instruments.
\end{abstract}

Analiza porównawcza instrumentów wsparcia finansowego wspólnej polityki rolnej z lat 2007-2013 w stosunku do lat 2014-2020

W artykule podjęto temat finansowania Wspólnej Polityki Rolnej, który rozpatrywano w układzie dwóch grup krajów Członkowskich, dwóch filarów WPR oraz na tle dwóch okresach programowania 2007-2013 i 2014-2020. Z badań wynika, że dawne państwa członkowskie (UE-15), dysponujące 71,3\% referencyjnych powierzchni gruntów wykorzystywanych rolniczo, partycypowały w środkach wsparcia finansowego w ramach I filara WPR na poziomie - w pierwszym okresie 84,0\%, w drugim zaś przypadku na poziomie 77,7\%. Oznacza to, że w ramach Unii Europejskiej zmierza się stopniowo do wyrównania dopłat bezpośrednich. Drugi filar WPR będący lustrzanym odbiciem ogólnej sytuacji w łącznym budżecie wspólnej polityki rolnej, zajmuje pozycję na poziomie jednej trzeciej instrumentów wsparcia finansowego. 